\title{
Ice-free intervals continuing into Marine Isotope Stage 3 at Sokli in the central area of the Fennoscandian glaciations
}

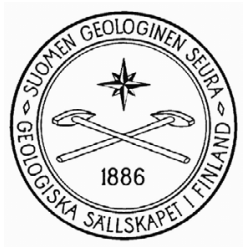

\author{
Karin F. Helmens ${ }^{1 * *}$, Peter W. Johansson ${ }^{2)}$, Matti E. Räsänen ${ }^{3)}$, \\ Helena Alexanderson ${ }^{1)}$ and Kari O. Eskola ${ }^{4)}$ \\ 1) Department of Physical Geography and Quaternary Geology, Stockholm University, 10691 \\ Stockholm, Sweden \\ 2) Geological Survey of Finland, P.O. Box 77, FI-96101 Rovaniemi, Finland \\ 3) Department of Geology, University of Turku, FI-20500 Turku, Finland \\ 4) Dating Laboratory, University of Helsinki, P.O. Box 64, 00014 Helsinki, Finland
}

\begin{abstract}
An unusually long and continuous Late Quaternary sedimentary sequence has been preserved in a sedimentary basin formed in the Sokli Carbonatite Massif in eastern-central Finnish Lapland. A nearly complete sediment recovery from the central Sokli basin combined with palynological results from sediments not earlier recovered and an independent OSL/AMS ${ }^{14} \mathrm{C}$ chronology allow us here to define the Late Quaternary climate-stratigraphy at Sokli and describe in detail the environmental record. Three interstadial intervals of Weichselian age are distinguished that correlate with MIS 5c, 5a and part of MIS 3 in the marine oxygen-isotope record. The interstadials of MIS $5 c$ and 3 age are here defined as the Sokli and Tulppio Interstadials, respectively. The MIS 5a interstadial is correlated with the Maaselkä/Peräpohjola Interstadials of Finnish Lapland, which previously have been tentatively assigned a MIS $5 \mathrm{c}$ age. Till beds in the Sokli sequence (deposited during stadials 3I) correlate to MIS 5b, 4 and 3/2, respectively. Depositional environments and vegetational changes during the ice-free intervals at Sokli are discussed. The Sokli sedimentary sequence indicates significantly less extensive and more variable ice-cover over Finnish Lapland during the Weichselian than has been earlier suggested based on the long-distance correlation of litho- and bio-stratigraphic fragmentary evidence.
\end{abstract}

Key words: glacial geology, sediments, stratigraphy, pollen analysis, paleobotany, climate change, interstadial environment, interglacial environment, chronology, Pleistocene, Sokli, Lapland Province, Finland

*Corresponding author email: karin.helmens@natgeo.su.se

\section{Introduction}

The Sokli sequence represents a for Fennoscandia unusually long and continuous sedimentary sequence that spans over the Last Interglacial-Glacial cycle and the Present Interglacial, i.e. representing the last ca.
$130 \mathrm{ka}\left(10^{3}\right.$ years). The sediments have been preserved in a small sedimentary basin formed in the Sokli Carbonatite Massif in eastern-central Finnish Lapland. The Sokli basin was situated under the easternmost 


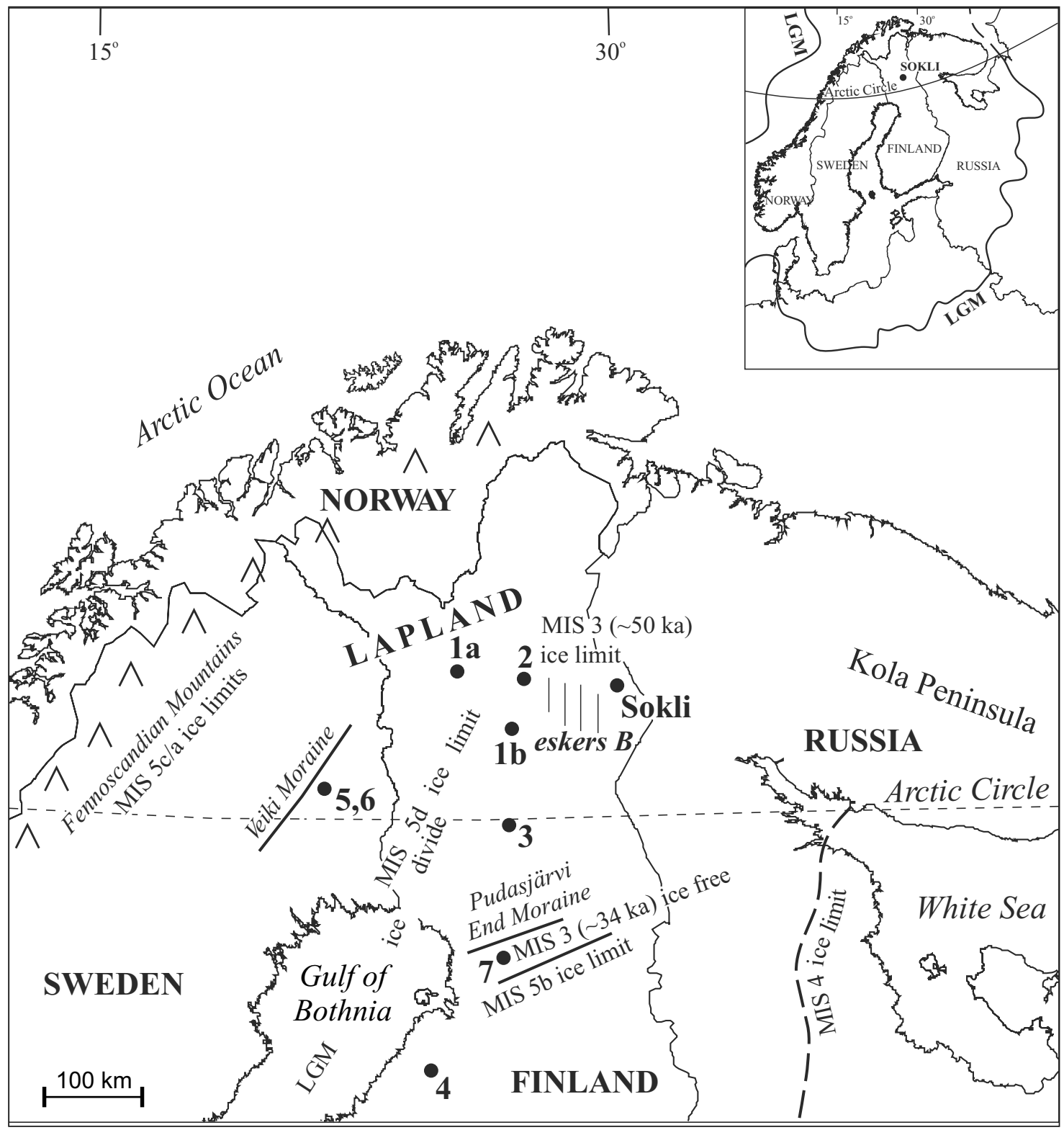

Fig. I. Map of northern Fennoscandia with the Sokli basin in eastern-central Finnish Lapland. In addition to the Sokli basin, which is the type locality for the Sokli and Tulppio Interstadials, type localities in northern Finland and Sweden are shown: $\mathrm{Ia}=$ Paloseljänoja, Ib =Tepsankumpu (type localities for Tepsankumpu Interglacial); 2 = Maaselkä Interstadial; 3 = Permantokoski (type locality for Peräpohjola Interstadial); 4 = Oulainen Interstadial of Swedish Norrbotten; 5 = Onttovaara, Onttoharjut, Takanenmännikkö, Riipiharju (type localities for the older interstadial); 6 = Tärendö Interstadial. 7 indicates the lijoki site (Ukkonen et al, 2000). The ice-limits of the Fennoscandian IceSheet during MIS 4 and MIS 2 (LGM) are taken from (Svendsen et al., 2004). Based on the data discussed in the present paper, possible ice-limits for MIS 5d, 5b and part of MIS 3 are indicated. Permanent ice-cover during MIS $5 \mathrm{c}$ and $5 \mathrm{a}$ was most probably restricted to the Fennoscandian mountains (Lundqvist, 1992). The LGM ice-divide is according to Siegert et al. (1999). 
part of the ice-divide zone of the Fennoscandian IceSheet during the Late Weichselian Glaciation Maximum (LGM at $20 \mathrm{ka}$; Fig. 1). The sequence consists of fossil-rich lacustrine sediments that alternate with a series of glacial-deglacial sequences consisting of till overlain by ice-marginal fluvial sediment. A fluvial deposit with a large contribution of slope material occurs intercalated near the base of the sequence.

A first study of the Sokli sedimentary sequence by Helmens et al. (2000) had allowed the identification of a series of warm and cold stage intervals. The stratigraphic sequence presented in Helmens et al. (2000), however, was in part composite as a result of incomplete borehole recoveries. It is based on a correlation of litho-/bio-stratigraphic evidence from the central part of the basin, i.e. where the sedimentary sequence is thickest and most differentiated, with that from the basin's margin. Moreover, with the exception of bracketing, preliminary luminescence dates for the Eemian Interglacial, age control was mostly based on stratigraphic correlation: the sequence shows for both the warm and cold stages of the Weichselian progressively colder conditions as the period evolves. This is also registered in the marine oxygen-isotope record and the climate/chrono-stratigraphic scheme of the northwest European mainland. As such, a marine oxygen-isotope stage (MIS) 3 age was tentatively assigned to the youngest interstadial interval with icefree conditions at Sokli.

In western Europe, sedimentary sequences that provide a continuous environmental record for the Last Interglacial-Glacial cycle are rare. Long continuous palynological records have been retrieved from southern sites in France (e.g. Guiot et al., 1989). The Late Quaternary climate-stratigraphy of the northwest European mainland is composite and based on correlation of bio-stratigraphic evidence (e.g. Zagwijn, 1985; Andersen \& Mangerud, 1989). The only well-documented site with interstadial deposits of Middle Weichselian age (MIS 3) found in sequence with Early Weichselian Interstadial and Eemian Interglacial sediments (MIS 5a, c and e, respectively) is the Oerel site in northern Germany (Behre, 1989), which is situated just south of the LGM limit of the Fen- noscandian Ice-Sheet. Further northwards, in Fennoscandia, the record becomes highly fragmented, and in the absence of absolute chronologies, the age assignments to the stratigraphic fragments that are found here are based on long-distance correlation of bio-stratigraphic data with the northwest European mainland stratigraphy (e.g. Donner, 1996).

High-resolution oxygen-isotope studies of ice cores from Greenland have revealed a higher climate variability for the Weichselian than indicated by the marine oxygen-isotope record (e.g. Johnsen et al., 2001). The predominantly westerly atmospheric circulation over western Europe makes it a key area to study the frequent large and abrupt climate changes (referred to as Dansgaard-Oeschger (D/O) events) recognized in the Greenland records. High climate variability for the Weichselian has been inferred from long pollen records in the Mediterranean region (Allen et al., 1999). Yet, northwards, the generally discontinuous nature of sedimentation and repeated erosion combined with poor dating control and a scarcity of highresolution sequences hamper the recognisation of the $\mathrm{D} / \mathrm{O}$ climate variability in the continental record. In addition, the highly fragmented nature of the stratigraphic record in Fennoscandia means that still many uncertainties exist in the Weichselian glaciation history that has been reconstructed for the Fennoscandian Ice-Sheet (e.g. Mangerud, 1991; Saarnisto \& Lunkka, 2004).

Here we present a new borehole that represents a nearly continuous sediment recovery from the central Sokli basin. The lithological data and newly obtained palynological data from the sediments that were not earlier recovered from the central basin allow us now to define the Late Quaternary climate-stratigraphic sequence at Sokli and describe in more detail the environmental record. The data presented here confirms the composite stratigraphy as presented in Helmens et al. (2000). In addition, an independent absolute chronology is given for the Weichselian sediments, based on optically stimulated luminescence (OSL) dating, which supports the earlier made stratigraphic correlation with the northwest European mainland and the deep sea. We will discuss our results in the 
context of the existing stratigraphic schemes of Finnish and Swedish Lapland and the Weichselian glacial history of northeast Fennoscandia.

Furthermore, this paper forms a stratigraphic basis for detailed studies of the Sokli sequence that are presently in progress. These include high-resolution, multi-proxy analyses (sediment characteristics, pollen, macro-botanical remains, chironomids, diatoms) of the thick and highly differentiated non-glacial sediment intercalations. Modern plant/animal-climate transfer functions will be applied to the fossil data in order to obtain quantitative climate records for a series of time intervals of Late Quaternary age. This will provide a unique possibility to study in detail Late Quaternary climate variability in the northern Atlantic region based on a terrestrial sediment archive.

\section{Study area}

Despite of the fact that during the Weichselian the Sokli area was repeatedly glaciated by the Fennoscandian Ice-Sheet, till beds and ice-marginal fluvial sediments deposited during glacial events, as well as lacustrine and fluvial sediments that were laid down in the Sokli basin during ice-free intervals, were not eroded. This has allowed the preservation of a sediment sequence that represents 5 major climate cycles of Late Quaternary age (described below).

The Sokli basin (lat. $67^{\circ} 48^{\prime} \mathrm{N}$, long. $29^{\circ} 18^{\prime} \mathrm{E}$; Fig. 1) is situated in a zone that stretches over central Swedish and Finnish Lapland and onto the Kola Peninsula in Russia, in which a whole array of sediments and landforms predating the LGM is found. Their preservation is ascribed to limited glacial erosion due to low ice velocities under the LGM icedivide zone of the Fennoscandian Ice-Sheet and/or frozen bed conditions (Kleman et al., 1999; Boulton et al., 2001). Central Finnish Lapland holds a distinct concentration of findings of sub-till organic beds (Hirvas, 1991). A close examination of the latter data, however, shows that most organic beds are truncated and are only a few centimetres or decimetres thick, and many occur in a secondary position. Outside the Sokli basin, there is not any site recorded in central Finnish Lapland with clear evidence for two or more warm stage deposits preserved in sequence. The unique preservation at Sokli of 4 nearly complete warm stage deposits predating the Holocene, interlayered with mostly till, can therefore not solely be ascribed to specific conditions at the base of the Fennoscandian Ice-Sheet.

An important additional factor in the preservation of the Sokli sediments is most probably the atypical local bedrock conditions. The Sokli basin (covering a surface area of ca. $2 \mathrm{~km}^{2}$ ) is formed in the central part of the Sokli Carbonatite Massif. This massif represents a Palaeozoic (ca. 360 Ma old) carbonate-rich magma intrusion of only very limited extent (diameter ca. $6 \mathrm{~km}$ ) into the surrounding crystalline rocks of the Precambian Shield (Vartiainen, 1980). Either a deep weathering depression, or a depression carved out in the relatively soft, deeply weathered and fractured rocks of the central Carbonatite Massif during Saalian glaciation (MIS 6, i.e. when the ice-divide zone was situated over northernmost Lapland (Hirvas, 1991)), has offered the additional protection for the sediments again erosion.

The Sokli mire and riverlet at $220 \mathrm{~m}$ elevation (a.s.l.) are surrounded by gently sloping forested flanks of hills reaching elevations of around $300-$ $350 \mathrm{~m}$ (see map in Helmens et al., 2000). Zonal vegetation consists of northern boreal forest with pine ( $P i$ nus sylvestris), birch (Betula pubescens and Betula pendula) and spruce (Picea abies). The present climate is cold temperate with a mean July temperature of $13^{\circ} \mathrm{C}$ and a mean February temperature of $-14^{\circ} \mathrm{C}$. Annual precipitation is between 500 and $550 \mathrm{~mm}$ (Atlas of Finland, 1992). At ca. $100 \mathrm{~km}$ north of Sokli, the boreal forest gives way to pine forest and then to sub-arctic birch forest. The forest limit at ca. $300 \mathrm{~km}$ north of Sokli is formed by the polycormic mountain birch Betula pubescens subsp. tortuosa. The vegetation of the tundra region beyond the forest limit is mainly a dwarf-shrub tundra dominated by dwarf birch (Betula nana) and Ericales (Ahti et al., 1968). 


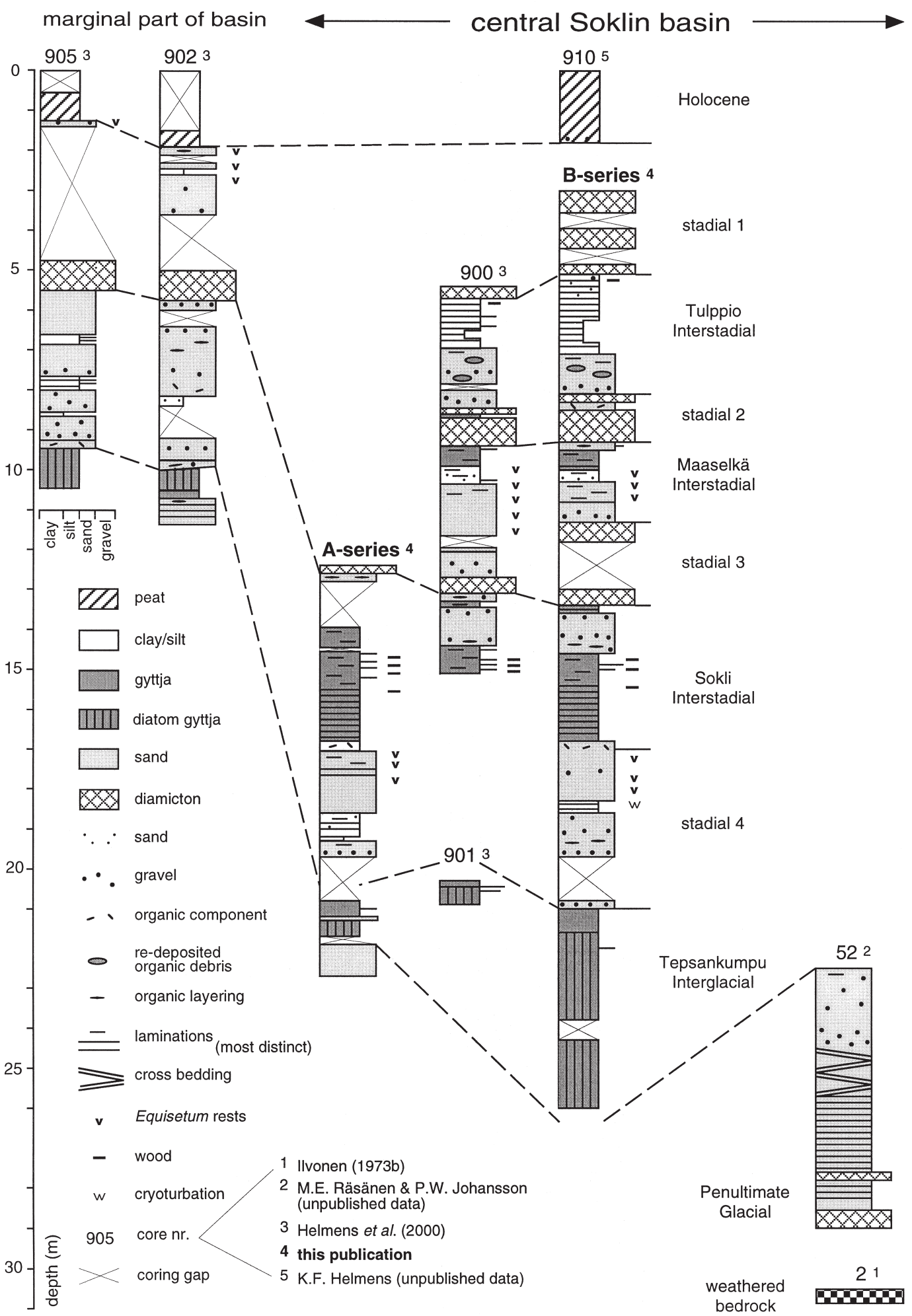

Fig. 2. Comparison of the new boreholes Sokli A- and B-series with earlier obtained borehole lithologies from the Sokli basin. Boreholes A- and B-series and boreholes $900 / 90$ I were taken within a few meter distance from each other. Borehole 52 was taken ca. ten metre to the NE and boreholes 902/905 (from the margin of the basin) ca. thirty metre to the SW of the central cores. For location of boreholes 900/90I and 902/905 see map in Helmens et al. (2000). The Late Quaternary climate-stratigraphic units indicated at the right side of the figure are discussed in the text. 


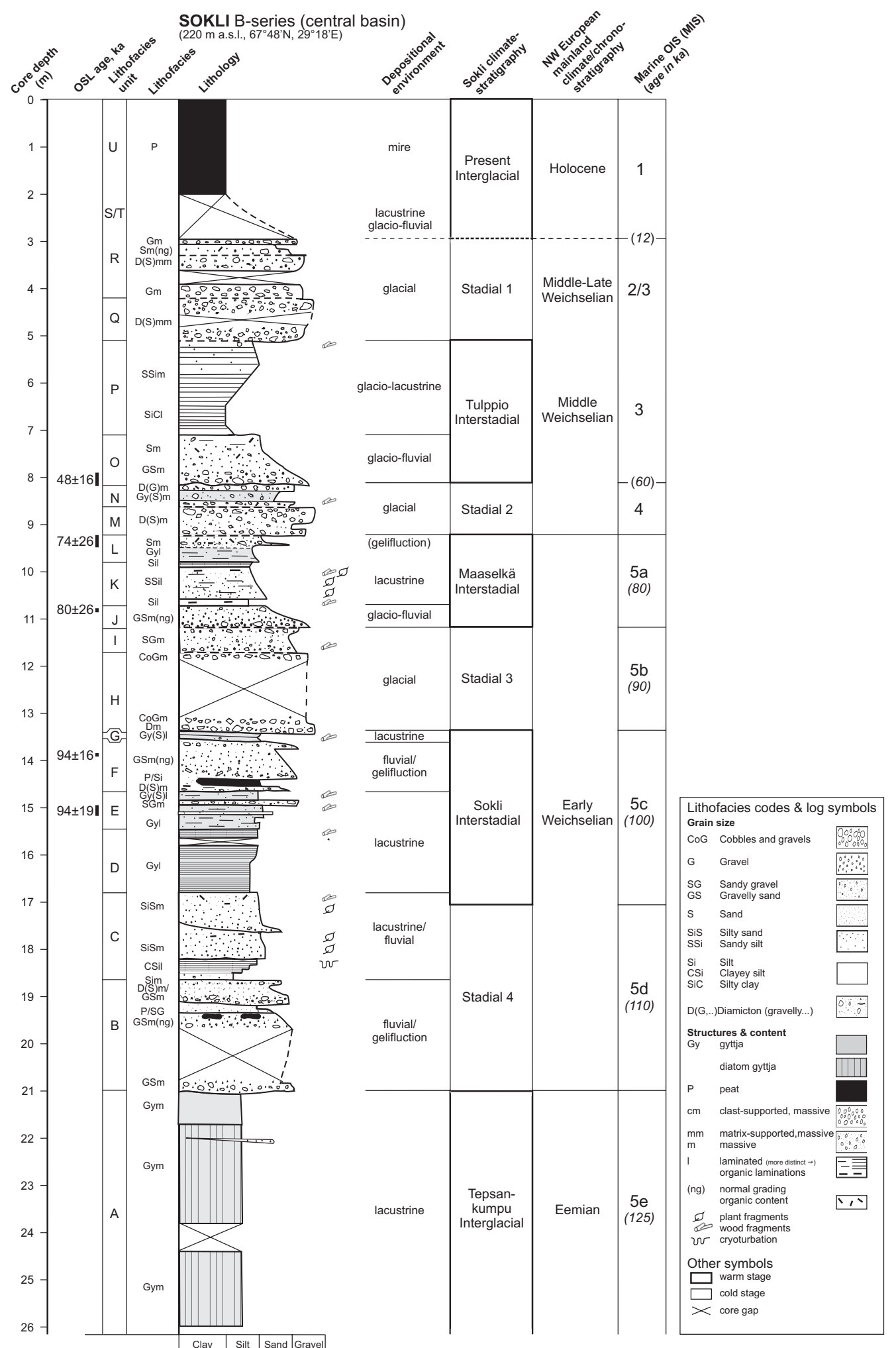

Fig. 3. Simplified lithological column of the Sokli B-series borehole from the central Sokli basin. A first interpretation in terms of former depositional environments is indicated directly to the right, and the OSL dates obtained on the borehole are indicated to the left. The Late Quaternary climate-stratigraphic sequence at Sokli and its correlation with the northwest European mainland climate/chrono-stratigraphy and marine oxygen isotope stratigraphy as indicated at the right side of the figure are discussed in the text. 


\section{Materials and methods}

Boreholes 900/901 and 902/905 in Helmens et al. (2000) represented the most continuous sediment recoveries from the central and marginal parts of the Sokli basin, respectively, that had been obtained so far (Fig. 2). Earlier information on the sedimentary sequence, which was in part based on drilling carried out in connection with carbonatite prospecting, had been rather fragmented (Ilvonen, 1973a,b; Forsström, 1990; Johansson \& Räsänen, 1994; Räsänen $\&$ Johansson, unpublished data). In the lithological column for the central basin presented in Helmens et al. (2000), however, a major coring gap separated the Eemian Interglacial sediments from the first Weichselian interstadial bed (boreholes 901 resp. 900 in Fig. 2). This coring gap was mostly closed in the winter of 2002 with the coring of boreholes Sokli A- and Bseries, which were taken at distances of 1-2 m apart from boreholes 900/901.

The Sokli B-series borehole has only minor gaps corresponding with the coarsest sediment layers. Its borehole lithology is shown in more detail in Figure 3. The sequence of lithofacies units $\mathrm{A}-\mathrm{U}$ indicated to the left of the lithological column is distinguished here to facilitate the description and interpretation of the borehole's lithology (see below); formal definition of stratigraphic units in the Sokli sedimentary sequence will be presented in a forthcoming paper. Although the thickness of the surface peat deposit was recorded at the coring site, the Holocene sequence was not recovered in the coring operation. The coring was carried out by the Geological Survey of Finland. Use was made of a hydraulic piston corer (GM 100) designed by Mr. Seppo Putkinen. Cores were taken into a dark coloured PVC tube, $2 \mathrm{~m}$ long and $4 \mathrm{~cm}$ in diameter, which was driven by vibration into the sediment while inserted in a steel tube. The surface peat deposit in the central basin has recently been collected by hand-coring (borehole 910 in Fig. 2).

A simplified pollen diagram with curves of selected taxa which summarizes the palynological analyses carried out by Helmens et al. (2000) and in the present study is given in Figure 4. Whereas Helmens et al. (2000) distinguished a sequence of pollen assemblage zones, we here introduce a numbering in the pollen zonation (pollen zones I-VI), that follows the climate-stratigraphic sequence described below. A formal description of Biozones will be presented upon completion of the high-resolution pollen analyses that are presently in progress. The pollen data corresponding to pollen zones II, IIIa-b, and IVa are presented here for the first time. We applied a similar sample preparation, microfossil analysis, pollen sum, construction of pollen diagram (e.g. calculations of microfossil percentages) and their interpretation (which uses modern vegetation-pollen relationships), as outlined in Helmens et al. (2000).

The optically stimulated luminescence (OSL) measurements that have provided the ages indicated to the left of the lithological column of Sokli B-series core in Figure 3 were made at the Dating laboratory of the University of Helsinki. The OSL datings were made on quartz using a SAR protocol (Murray $\&$ Wintle, 2000). Sampling was focused on water transported sediments, e.g. glacio-fluvial or fluvial sediments, as these are probably most well-bleached. The ages were corrected for water content. A saturated water content was assumed to represent a good approximation of the average water content since time of deposition, because the Sokli site is situated in a depression where today is a peatland, and in the past repeatedly a lake, and the sampled sediments were all taken below the average groundwater table. The rather large error limits on the final dates are mainly due to the luminescence properties of the analysed sediment and the sampling technique (i.e. coring) which resulted in small sample sizes and uncertainties in dose-rate determinations. Nevertheless, the dates are in sequence and can be separated into three age groups, which agree with the relative chronology as derived from stratigraphy (see below).

AMS ${ }^{14} \mathrm{C}$ ages of $>42,000 \mathrm{yr}$ BP and $42,450 \pm$ 3,570 yr BP have been previously obtained from the uppermost parts of lithofacies units $\mathrm{L}$ respectively $\mathrm{P}$ (Fig. 3) in the parallel borehole 900 (Fig. 4; see below). Both wood samples (Table 1 in Helmens et al., 2000) underwent a thorough chemical pre-treatment 


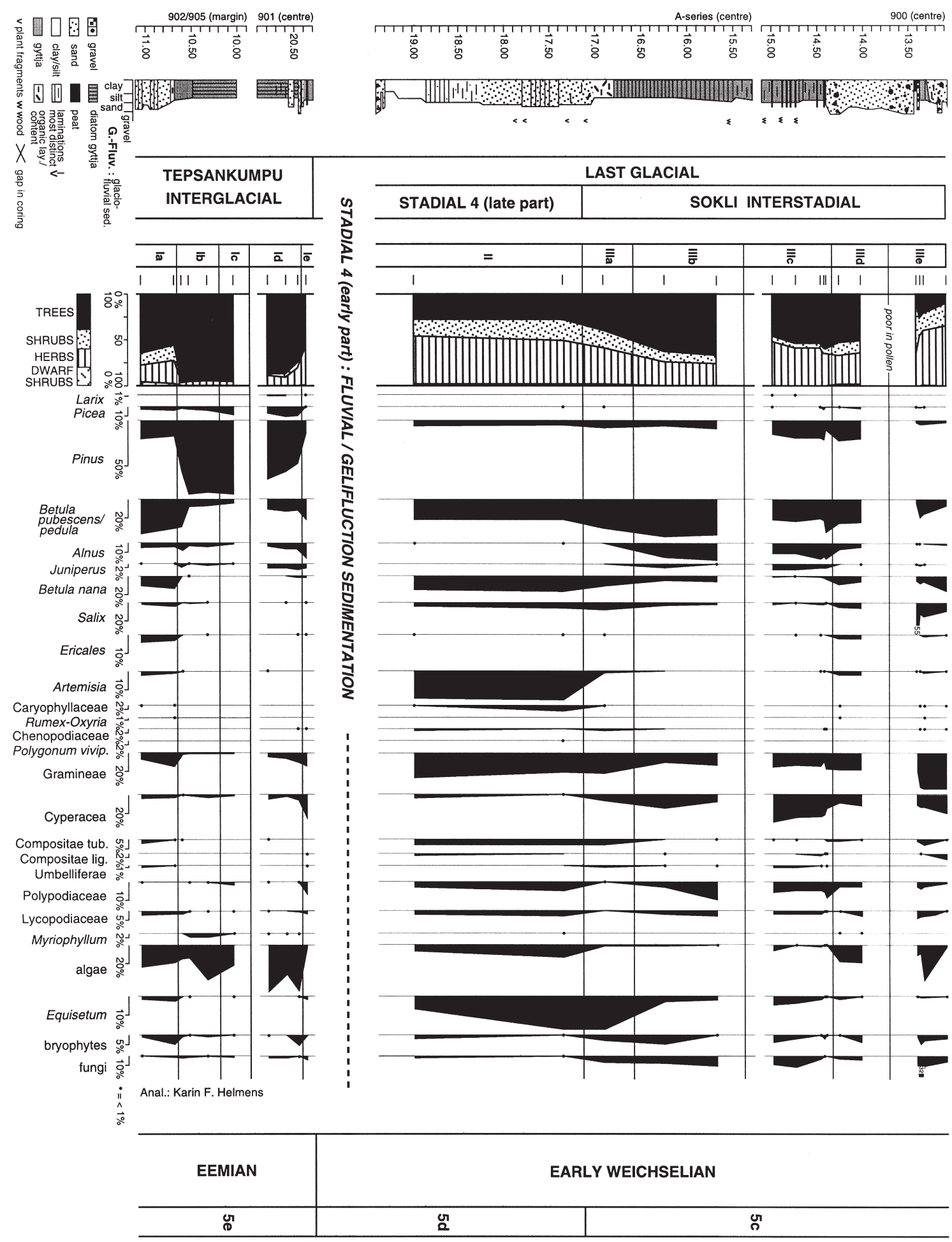

Fig. 4. Late Quaternary pollen stratigraphy at Sokli. The simplified pollen diagram summarizes the palynological results obtained in Helmens et al. (2000) and the present study (borehole Sokli A-series). The Late Quaternary climate-stratigraphic sequence at Sokli and its correlation with the northwest European mainland climate/chronostratigraphy and marine oxygen isotope stratigraphy are discussed in the text. 


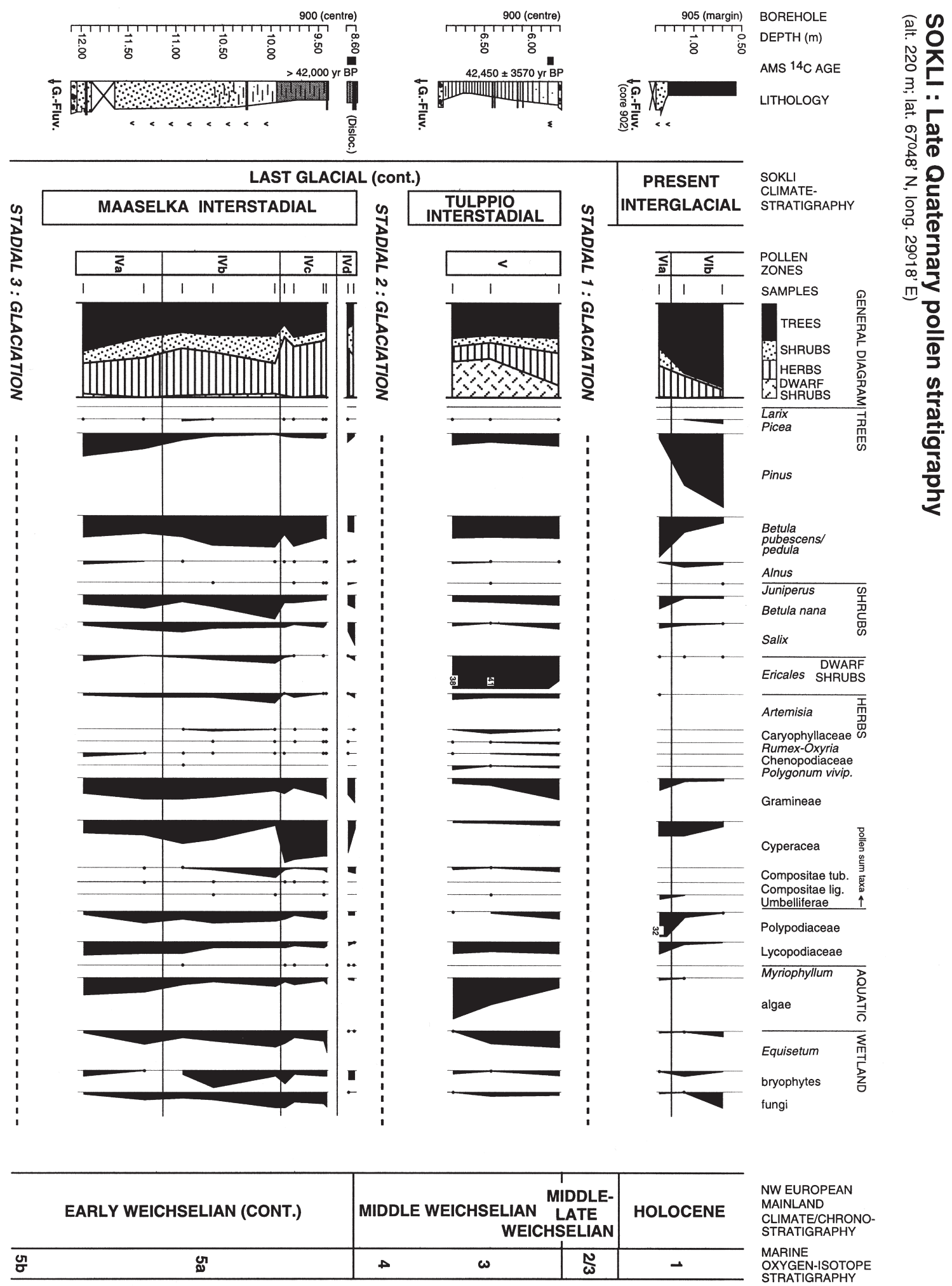


to remove possible contaminants. Therefore, the date for the youngest interstadial sediments was accepted as a finite age, although it is close to the limit of the radiocarbon dating method (Helmens et al., 2000). The latter date agrees, within error limits, with the OSL date obtained from the same stratigrapic unit (Fig. 3).

\section{Late Quaternary climate-stratig- raphy and environmental record at Sokli}

The lithological, palynological and absolute chronological data now available from the Sokli basin allows us here to distinguish a sequence of Late Quaternary climate-stratigraphic units and discuss the environmental record in more detail than presented in Helmens et al. (2000).

Where possible, based on bio-stratigraphic evidence, warm stage units in the Sokli sequence are correlated with previously named interglacials/interstadials in central Finnish Lapland. Palynological/ lithological sequences that could correlate with the oldest and youngest Weichselian interstadial deposits at Sokli have not been previously described, and these interstadials are here defined for the first time. Although the number of till beds in the Sokli basin conforms to the Weichselian till stratigraphy of eastern central Lapland (Johansson, 1995), small sample sizes due to our sampling technique (i.e. coring) precludes a detailed study of the glacial deposits in the Sokli basin, and this hampers a direct collection with the till beds found exposed in the surrounding region. Furthermore, the oldest cold stage interval of Weichselian age at Sokli was not characterized by glaciation, but instead is represented by fluvial/lacustrine deposits with an arctic pollen content. Therefore, we here introduce a sequence of cold stage intervals for the Weichselian at Sokli, which we number from youngest to oldest as stadials 1-4.

In the description of the climate-stratigraphy below, units are grouped into 5 major climate cycles of Late Quaternary age, each cycle starting with cold stage conditions. Correlation with the northwest Eu- ropean mainland and marine stratigraphies is supported by the independent absolute chronology for the Sokli sequence (Figs. 3 and 4). The lithological and palynological evidence, which allow us to reconstruct the environmental conditions for each climatestratigraphic unit at Sokli, will be discussed in an integrated way, as former changes in depositional environments seem generally to have been closely related to changes in vegetation and climate. The discussion makes use of the lithological data presented in Figure 3 (lithological units $\mathrm{A}-\mathrm{U}$ ) and in part Figure 4, and the palynological data as summarized in Figure 4 (pollen zones I-VI). For the earliest part of the sequence (i.e. transition from the Late Saalian to Eemian) and the latest part (Late Weichselian-Holocene transition), reference is made to previously published borehole lithologies.

In addition to a correlation with, or reference to, bio- and litho-stratigraphic data from central and southern Lapland, and central Ostrobothnia further to the south, the Sokli record will be compared with morpho-stratigraphic evidence from eastern central Lapland. The latter stratigraphy includes a series of sizeable cross-cutting eskers, several of them till-covered (Fig. 5; Johansson, 1995; Johansson \& Kujansuu, 1995).

\section{I.The Last Interglacial (MIS 5e): the Tepsankumpu Interglacial}

Drilling carried out by Räsänen \& Johansson (unpublished data) indicates for the depth interval 23$29 \mathrm{~m}$ in the central Sokli basin a series of upward coarsening, parallel and cross-bedded sands to gravel on top of diamicton (core 52 in Fig. 2). These sands and diamicton, which underlie the Last Interglacial bed, rest on weathered bedrock at a depth of ca. $30 \mathrm{~m}$ according to drilling information presented in Ilvonen (1973b). These oldest sediments in the Sokli sequence most probably represent the end phase of the Saalian Glaciation (MIS 6) and the subsequent transition towards the Last Interglacial.

A distinct interglacial pollen sequence is present in a diatom gyttja bed that as a marker horizon stretches through the Sokli basin near the base of the uncon- 
solidated sediment infill. The interglacial pollen flora was first noted by Ilvonen (1973a) and the pollen sequence was studied in detail by Forsström (1990). The sediments that were analysed in Forsström (1990), however, had been collected with auger from the marginal part of the basin. They not only showed evidence for a hiatus in the upper part of the interglacial sequence, but also provided little detailed information on the sedimentary sequence. Helmens et al. (2000) tried to collect samples from the diatom gyttja bed in the central part of the basin, but at a depth of ca. $20 \mathrm{~m}$ only reached its upper part (borehole 901 in Figs. 2 and 4). The early part of the interglacial vegetation development was therefore studied in sediment cored from the basin's margin (boreholes 902/905 in Figs. 2 and 4). The bed was found highly compacted during the coring operation. The diatom gyttja deposit has a thickness of up to several meters (Ilvonen, 1973b) and was for an important part collected from the central basin with improved coring equipment in 2002 (unit A in Fig. 3).

The pollen assemblage in stratified sands directly underlying the diatom gyttja bed (pollen zone Ia in Fig. 4), which includes high pollen percentages for tree birch (Betula pubescens/pendula) and dwarf birch (Betula nana), indicates a regional vegetation that probably resembled the present vegetation near the sub-arctic forest limit in Finnish Lapland, i.e. where open birch forest passes into shrub tundra. As the sands turn to sandy gyttja and then to massive diatom gyttja, the pollen sequence reveals the start of a warming trend that allowed pine forest to gradually develop on the hill slopes surrounding the Sokli basin (zone Ib). The next phase in forest development shows the establishment of northern boreal forest, with first the immigration of spruce (zone Ic) and then that of larch (zone Id). The boreal forest with larch seems to have had a more open character than the present boreal forest in the Sokli area, allowing Juniperus pollen to significantly contribute to the NAP. Although the last interglacial climate had become at least as warm as that of today, it might have had a more continental character. The present range of larch starts some 500 $\mathrm{km}$ east of Sokli, where with increasing continentali- ty Larix sibirica becomes an important component of the Russian northern taiga. Sedimentation of diatom gyttja continued during the establishment of boreal forest, although near the end of this phase it was repeatedly interrupted by the deposition of sandy and gravelly sediment. An abundance of algae, relatively high pollen percentages for the aquatic plant Myriophyllum, together with a near absence of wetland elements, indicate that throughout the deposition of diatom gyttja, the Sokli basin was occupied by a relativelly deep lake that was surrounded by only a limited zone of wetland vegetation.

A marked cooling in climate indicated by a reversed, southerly shift in the northern forest limit is registered by the pollen found in sandy gyttja overlying the diatom gyttja deposit. Pollen zone Ie suggests the presence of birch forest with larch and alder. At present, stands of Larix sibirica, Betula pubescens subsp. tortuosa (mountain birch) and Alnus (Ducheckia) fruticosa are found near the forest limit in the Russian Polar Urals (Igoshina, 1963; Flora of northeast European Russia, 1976).

A minimum OSL age of ca. $95 \mathrm{ka}$ (Fig. 3) combined with its stratigraphic position indicate that the interglacial diatom gyttja bed and associated sandy sediment found near the base of the Sokli sequence most probably represent the northwest European mainland Eemian Interglacial or MIS 5e dated in the marine record between ca. 125 and $110 \mathrm{ka}$ (Martinson et al., 1987). The Last Interglacial has been defined as the Tepsankumpu Interglacial in Finnish Lapland (Hirvas, 1991). The type localities are Tepsankumpu and Paloseljänoja (Fig. 1), where the lower respectively upper parts of the interglacial sequence have been preserved. The pollen sequence shown at the latter sites (Saarnisto et al., 1999) is very similar to the one described above at Sokli.

\subsection{The first stadial-interstadial sequence of Early Weichselian age (MIS 5d-5c): stadial 4 and the Sokli Interstadial}

A thick sequence of silts and sands was found by Forsström (1990) overlying the interglacial gyttja depos- 
it along the basin's margin. These sediments were interpreted to have a possible glacial origin and their pollen content as re-deposited, representing the upper parts of the underlying interglacial bed. The silt/ sand sequence revealed in its lower part an open tundra pollen assemblage, whereas in the upper part, where the silts turn slightly more organic, a birch forest assemblage was found. A pollen assemblage similar to the latter birch forest assemblage was subsequently encountered by Helmens et al. (2000) in a thick gyttja horizon in the central basin (borehole 900 in Fig. 3). As also in the central part of the basin the gyttja horizon with the birch forest pollen assemblage seemed to be separated from the interglacial bed by a thick sequence of mostly sandy sediment, Helmens et al. (2000) concluded that the sequence outlined in Forsström (1990) mostly probably occurred in situ, recording a stadial-interstadial sequence. The sandy sediments had not been cored by Helmens et al. (2000), but their occurrence in the central basin was inferred from earlier obtained borehole information (Räsänen \& Johansson, unpublished data). The major coring gap of ca. $5 \mathrm{~m}$ that separated the interglacial bed from the first interstadial bed in the central basin (i.e. between boreholes 900 and 901, Fig. 2) was mostly closed in 2002 with the coring of boreholes Sokli B- and A-series (Figs. 2-4). The lithological and palynological data presented here confirm the stratigraphy as presented by Helmens et al. (2000) and provide detailed information on the first stadial-interstadial sequence following MIS 5e. Sediments with a pollen sequence similar to the oldest interstadial sediments at Sokli have not been earlier described from Finnish Lapland, and the first interstadial interval of Weichselian age is here defined as the Sokli Interstadial. The first cold stage interval is numbered stadial 4 .

The early part of stadial 4 is represented by a gravelly deposit showing distinct upward-fining trends (unit $\mathrm{B}$ in Fig. 3). The deposit has a most probably fluvial origin, although the angularity of the gravel fragments suggests a large contribution of slope material that was possibly transported down-slope under the influence of gelifluction. Slabs of organic matter that occur in sandy sediment, and which consist of a varie- ty of well-preserved moss remains, probably represent pieces of the eroded surface mat. The ca. $2 \mathrm{~m}$ thick silt/sand sequence that overlies the gravelly deposit shows at several depth intervals a distinct, mostly parallel layering (unit C; see also borehole A-series in Fig. 4). The silts and sands are interpreted to have been deposited in a more quiet fluvial environment than recorded in the underlying gravels, or in a shallow lake environment (late part of stadial 4). Distortion structures at the top of the first recorded stratified bed might represent disturbance under the influence of cryoturbation. Distinct arctic conditions at the time of deposition of the silt/sand sequence are reflected by its pollen content (pollen zone II in Fig. 4), which is very similar as described by Forsström (1990). Open tundra vegetation with the herbs Artemisia, Caryophyllaceae, Chenopodiaceae, Compositae and grasses (Gramineae), as well as shrubs of Betula nana and Salix, characterized the regional vegetation in the Sokli area. The representation of the algae Botryococcus in the microfossil assemblage points to aquatic conditions at the coring site, bordered/surrounded by wetland vegetation with Equisetum.

As the silt/sand sequence becomes more organic at a depth of ca. $17 \mathrm{~m}$, the pollen record indicates the start of a warming trend that continues into the overlying, over $2 \mathrm{~m}$ thick laminated gyttja bed (early part of the Sokli Interstadial). Pollen zone IIIa in the organic silts/sands represents a dramatic decrease in pollen percentages of Artemisia. Increased values for tree birch (Betula pubescens/pendula) suggest the nearby presence of the sub-arctic birch forest limit. The local vegetation near the coring site was enriched with $\mathrm{Po}$ tentilla, Cyperaceae, Sphagnum and fungi. Tree birch pollen percentages continue to rise in the lower part of the overlying gyttja deposit, and the pollen assemblage defined here (zone IIIb) resembles the one recorded near the end of the Tepsankumpu Interglacial (zone Ie): birch forest had returned to the Sokli area, in which alder (Alnus) was well-represented, and juniper (Juniperus) and fern stands (Polypodiaceae) formed important elements in the under-storey. Pollen zone IIIc in the upper part of the gyttja deposit, which is characterized by a distinct increase in $\mathrm{Pi}$ - 
nus pollen and a further decrease in dwarf birch (Betula nana) pollen, registers the subsequent approach of the pine forest limit, and the recorded pine pollen values suggest that pine trees formed part of the regional vegetation at Sokli forming a birch-pine forest. Alder, juniper and ferns were still well-represented and also larch formed part of the forest vegetation. Since larch is an extremely poor pollen producer (e.g. Ritchie, 1974), it is possible that stands of larch were already present during the preceding interval with birch forest vegetation, as they had been at the end of the Tepsankumpu Interglacial. Relatively high NAP values shown in the birch-pine forest pollen assemblage are related to an over-representation of pollen from sedges (Cyperaceae) from the local wetland vegetation, as findings of fungal remains of Gaeumannomyces indicate the nearby presence of Carex stands (Van Geel et al., 1983). The climate during the Sokli Interstadial had become nearly as warm as today, as the northern limit of pine is presently situated only some $200 \mathrm{~km}$ north of Sokli.

The thick gyttja deposit of the early part of the Sokli Interstadial is in its lowermost part rythmically interlayered with very thin silt laminea, and if the laminations have an annual origin (related to spring snow-melt), then some 900 years of sedimentation is recorded by unit D (Fig. 3). The gyttja bed becomes in its remaining part increasingly interlayered with sand (and in the uppermost part with some gravel) and wood (unit E). As the sand/wood deposition occurred while the climate became progressively warmer, it was most probably related with a change in local sedimentary conditions. The lake in which the Sokli Interstadial gyttja accumulated might have formed part of a floodplain and at intervals of high water became flooded by the adjacent river, or the coarsegrained intercalations were due to lateral change or prograding of sand and gravel deposition.

The deposition of sands and angular gravel starts to predominate from a depth of ca. $14.5 \mathrm{~m}$ upwards, and once again large slabs of organic matter similar as encountered in unit B were deposited at the coring site (unit F). Parallel to this change towards fluvial deposition in which sediment from the surrounding slopes formed an important contribution, the pollen record registers a reversed, southerly shift in the birch forest limit towards the vicinity of the Sokli basin, marked by strongly declining values of pollen of $\mathrm{Al}$ nus and Juniperus and spores of Polypodiaceae, and a distinct increase in pollen values for Betula nana, $S a$ lix, Ericales, and Artemisia (zone IIId). As during this cooling event also the pine forest limit can be expected to have shifted to a more southerly position, the still high percentages of Pinus pollen in zone IIId are most probably due to an over-representation of longdistance transported pine pollen as the vegetation at Sokli obtained a more open character (Aario, 1940; Prentice, 1978; Hicks, 1994). Short-term, laminated sandy gyttja deposition at the end of the Sokli Interstadial (unit G) was most probably related to a lateral shift in the local riverlet, as a distinct rise in NAP values indicates further cooling to arctic conditions (zone IIIe).

Two OSL ages of $94 \pm 19$ and $94 \pm 16$ ka for the Sokli Interstadial deposit, combined with stratigraphy, indicate that the first stadial-interstadial sequence recorded at Sokli following MIS 5e most probably correlates to the northwest European mainland Herning Stadial and Brørup Interstadial or MIS $5 \mathrm{~d}$ and $5 \mathrm{c}$ dated in the marine record at around 110 and $100 \mathrm{ka}$, respectively (Figs. 3 and 4).

A minor coring gap still separates the Tepsankumpu Interglacial sediments from the stadial 4 deposit in the central Sokli basin (see unit B in Fig. 3; Fig. 2). The sediment, which was lost in the coring operation, most probably consisted of loose sand or gravel. Coring information from the marginal part of the basin reveals unit B directly overlying the interglacial diatom gyttja bed (borehole 905 in Fig. 2). The Tepsankumpu Interglacial, stadial 4 and the Sokli Interstadial can be found as a unit both in the central and marginal parts of the Sokli basin. The occurrence of the younger interstadial deposits (described below) is restricted to the deepest central basin. 


\subsection{The second stadial-interstadial sequence of Early Weichselian age (MIS 5b-5a): stadial 3 and the Maaselkä Interstadial}

The cooling that started during the late part of the Sokli Interstadial eventually led to the glaciation of the Sokli area by the Fennoscandian Ice-Sheet. The glaciation is recorded by the deposition of over 2 $\mathrm{m}$ thick diamict deposit (Fig. 2). The diamicton is in its lower part clast supported (unit $\mathrm{H}$ in Fig. 3), whereas a sandy matrix dominates in its weakly stratified upper part (unit I), and the deposit is interpreted as representing basal till possibly overlain by ablation till. The clasts become distinctly more rounded and sorted at the base of unit J, and the upward-fining sediment sequence represented by this unit is interpreted as the subsequent deglaciation phase with ice-marginal fluvial sedimentation. Unit $\mathrm{H}$ was only partly collected during the most recent coring operation in 2002 (Fig. 3), as the equipment broke down on the coarse basal till.

The sediments continue to fine up to laminated sands and silts (unit K) and then to laminated sandy gyttja (unit L) in the overlying sediment sequence, which in borehole 900 attains a thickness of $2,5 \mathrm{~m}$ (Figs. 2 and 4). A thin bed of stratified silts interlayered with wood found directly overlying the glaciofluvial deposit might have a fluvial origin, but the laminated sands and silts on top, which contain abundant macrofossil remains of Equisetum sp, were most probably deposited in a shallow lake environment. The silts directly underlying the sandy gyttja horizon show a similar lamination as unit D near the base of the Sokli Interstadial gyttja deposit, with slightly organic silts being rythmically interlayered with very thin silt to fine sand laminea. The contact of the gyttja horizon with the overlying, second diamicton at a depth of ca. 9 to $9.5 \mathrm{~m}$ seems gradual in borehole Sokli B-series (Fig. 3), but is abrupt in borehole 900 (Figs. 2 and 4).

Directly following the deglaciation of the area, open tundra vegetation prevailed with Betula nana, Salix, Ericales, Artemisia, Chenopodiaceae and grasses (Gramineae), as well as lycopods (Lycopodiaceae) and ferns (Polypodiaceae). A low pollen production by the tundra vegetation, and/or its open character, allowed long-distance transported pine (Pinus) pollen to make a significant contribution to the sum of pollen zone IVa (Fig. 4). The algae Pediastrum, Botryococcus and Spirogyra are well-represented in the microfossil assemblage and indicate local aquatic conditions. Subsequently, a shift in the sub-arctic birch forest limit to the vicinity of the Sokli area is registered by decreasing values of Pinus pollen and an increase in tree birch (Betula pubescens/pendula) pollen (zone IVb). Although aquatic conditions continued to prevail at the coring-site, the microfossil record now reveals well-developed wetland vegetation within the Sokli Basin consisting of Cyperaceae, Equisetum, bryophytes and fungi. A forest limit vegetation most probably continued to characterize the regional vegetation in the Sokli area during the deposition of the gyttja bed (zone IVc), as the fungus Gaeumannomyces indicates that the high Cyperaceae values in the gyttja, which occur at the expense of other NAP elements, are derived from nearby Carex stands. The return of more open vegetation seems to be registered during the latest phase of gyttja deposition by an increase of long-distance transported pine pollen. The latter assemblage (zone IVd) has been described based on the pollen from a thin organic bed, that consists of laminated gyttja turning to sands interbedded with organic silts, and that was found interlayered in the overlying, second diamict deposit in borehole 900 (Fig. 2). The thin organic bed has been interpreted by Helmens et al. (2000) as representing part of the gyttja deposited previous to the diamicton, but which became dislocated during the subsequent glaciation. The laminated sandy gyttja deposit in borehole Sokli B-series (Fig. 2) becomes increasingly interlayered with sand and angular gravel before it turns to organic sands containing organic lamineae at the base of the second diamict bed.

OSL ages of $80 \pm 26$ and $74 \pm 26 \mathrm{ka}$ for the lower respectively upper part of the interstadial deposit, combined with stratigraphy, indicate that the second stadial-interstadial sequence of Weichselian age recorded at Sokli most probably correlates to the northwest European mainland Rederstall Stadial and 
Odderade Interstadial or MIS 5b and 5a dated in the marine record at around 90 and $80 \mathrm{ka}$, respectively (Figs. 3 and 4). The interstadial is correlated with the Maaselkä Interstadial as defined by Hirvas (1991) for central Lapland (see below). The cold stage interval is numbered stadial 3 .

\subsection{Correlation with the composite stratigraphic schemes of northern Finland}

The second Early Weichselian interstadial at Sokli has been correlated by Helmens et al. (2000) with the Maaselkä Interstadial of central Lapland (Hirvas, 1991), which is thought to correlate to the earlier defined Peräpohjola Interstadial of southern Lapland (Korpela, 1969). The pollen sequence at Maaselkä (Fig. 1) is recorded in sands and gyttja overlying till. A dominance of birch pollen combined with a high NAP is interpreted as representing a birch forest vegetation in the vicinity of the northern forest limit (Donner, 1995). A more open vegetation both at the beginning and the end of the interstadial is suggested by a slight increase in long-distance transported pine pollen. At Permantokoski (Fig. 1), the most representive site and later defined as the type locality for the Peräpohjola Interstadial (Donner et al., 1986), a several meters thick sand deposit overlain by an up to ca. $0.5 \mathrm{~m}$ thick peat horizon occurs interlayered in-between two till beds. The pollen sequence in the finegrained sediment intercalation at this more southerly located site, which is monotonously dominated by birch, is interpreted to represent birch forest. A peak in long-distance transported pine pollen is recorded at the bottom of the pollen sequence.

The Peräpohjola and Maaselkä Interstadials have been originally correlated with the northwest European mainland Brørup Interstadial (MIS 5c; Korpela, 1969; Donner et al., 1986; Hirvas, 1991), and the glaciation that is recorded by the underlying till bed with its NW fabric (Lower Till unit and Till bed III in the till stratigraphies of southern (Korpela, 1969) respectively central Lapland (Hirvas, 1991)) was thought to have occurred during the first cold stage interval of the Weichselian (Herning Stadial/MIS 5d).
An Odderade age (MIS 5a) for the Peräpohjola Interstadial, as suggested through correlation with the Sokli record, has been first suggested by Forsström (1988). Forsström (1988) argues that the differences in vegetation reflected in the pollen records from the Peräpohjola sites in southern Lapland and the pollen record that was later obtained from the Oulainen site to the south in central Ostrobothnia (Fig. 1; Forsström, 1982) are too great to be explained in terms of local or regional factors. The pollen record at the Oulainen site reveals a distinct vegetation development of birch forest to pine forest and back to birch forest, and the interstadial interval has been defined as the Oulainen Interstadial and correlated with the Brørup Interstadial (MIS 5c; Donner et al., 1986; Donner, 1988). According to Forsström (1988), the long phase with pine forest during the Oulainen Interstadial does not conform to the small amounts of pine pollen in the birch forest pollen assemblage of the Peräpohjola sediments found only a few hundred kilometers to the north. Therefore, it was suggested that the Oulainen and Peräpohjola Interstadials do not represent the same time interval, but the Oulainen sediments with the pine forest pollen assemblage would correlate to the Brørup and the Peräpohjola sediments holding a sub-arctic birch forest assemblage correlate to the slightly colder Odderade Interstadial.

In later publications, however, Forsström (1991) considers the possibility that the deposits in northern Finland that have been interpreted as representing an interstadial interval may instead represent the later stages of the Eemian Interglacial, but were redeposited in the course of Late Weichselian deglaciation. Variations in fabric of associated till beds are explained in the paper by changes in ice-flow direction during deglaciation. Forsström (1991) suggests that major part of Finland was glaciated throughout the Weichselian.

The data from the Sokli basin now supports the interpretation made by Forsström (1988). The first interstadial of Early Weichselian age (Brørup Interstadial/MIS 5c) in the Sokli basin, which in the present paper is defined as the Sokli Interstadial, represents a phase with birch-pine forest in central Lapland. This 
would conform to a time interval with pine forest at the most southern located Oulainen site in central Ostrobothnia (Oulainen Interstadial). The second interstadial of Early Weichselian age (Odderade Interstadial/MIS 5a) at Sokli most probably correlates to the Maaselkä/Peräpohjola Interstadials, showing the development of birch forest limit vegetation in central Lapland (Sokli and Maaselkä) and birch forest at the Peräpohjola sites in southern Lapland. The Maaselkä/Peräpohjola Interstadial represents an ice-free interval following glaciation of Lapland (glaciation during stadial 3 in the Sokli basin; Till Bed III and the Lower Till unit in central and southern Lapland, respectively; Rederstall Stadial/MIS 5b).
In the Sokli region in eastern-central Lapland, the so called 'Oldest Till unit' (with NW fabric) has been correlated by Johansson (1995) with Till bed III of Hirvas (1991). Although some of the oldest eskers that are distinguished in the region might have been deposited at the closing phase of the Saalian Glaciation (Kujansuu \& Eriksson, 1995), most are thought to have developed following the glaciation that deposited the Oldest Till unit (Johansson, 1995; Johansson \& Kujansuu, 1995). These till-covered eskers defined as esker system $\mathrm{C}$ (Fig. 5) are composed of massive remnants of formerly coherent esker ridges showing a NW-SE orientation. Also their compacted glacio-fluvial sediment reveals a clear reworking by glacial flow.

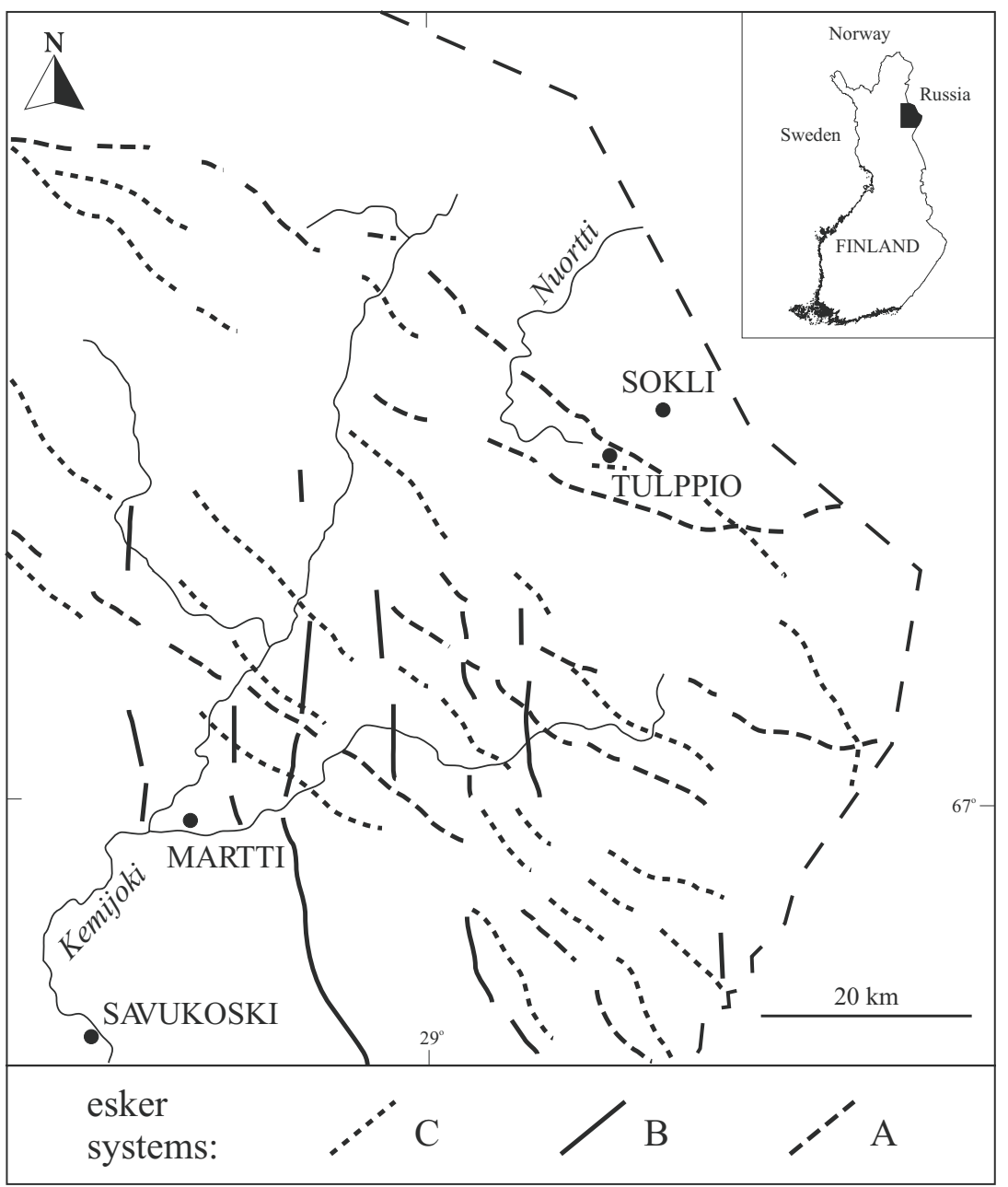

Fig. 5. Cross-cutting esker systems in eastern-central Finnish Lapland (Johansson, 1995; Johansson \& Kujansuu, 1995). The till-covered eskers of systems $C$ and B predate the Late Weichselian Glaciation Maximum (LGM) of the Fennoscandian IceSheet, and are in the present paper correlated with the Maaselkä and Tulppio Interstadials of Early respectively Middle Weichselian age. 


\subsection{The stadial-interstadial sequence of Middle Weichselian age (MIS 4-3): stadial 2 and the Tulppio Interstadial}

Lithological units $\mathrm{M}-\mathrm{O}$ (Fig. 3) represent the second phase of glaciation of the Sokli area during the Weichselian and the subsequent deglaciation with proglacial fluvial sedimentation. The till bed has a recorded thickness of about $1 \mathrm{~m}$. Palynological analysis has revealed that the organic sediment that is mixedin with the glacio-fluvial sediment in the upper part of unit $\mathrm{O}$ has its orgin in the interglacial diatom gyttja bed near the base of the Sokli sequence (Helmens et al., 2000). The interglacial gyttja bed has the most widespread occurrence of the older organic sediments within the Sokli basin, and therefore is most likely to be re-accounted for as re-deposited organic debris.

The glacio-fluvial deposit, which in its upper part becomes increasingly parallel layered, is overlain by an up to ca. $2 \mathrm{~m}$ thick minerogenic, fining upward and then coarsening upward, laminated silt-clay sequence (unit P). The silts and clays most probably accumulated in a glacio-lacustrine environment, and the sediment sequence is interpreted as reflecting a retreating and subsequent approaching ice-front. Wood fragments and what seems to be a dropstone in the uppermost part of the glacio-lacustrine deposit suggest overriding of the vegetation by the approaching ice-front and subsequent deposition of the plant fragments in the lake. The contact with the overlying basal till of the third glaciation (unit Q) seems gradual.

Palynological evidence indicates that during the interstadial interval, the higher, deglaciated land became covered with shrub tundra (pollen zone $\mathrm{V}$ in Fig. 4). The shrub tundra vegetation was dominated by Ericales and was charcaterized by a highly diverse herb flora with a variety of arctic-alpine and heliophilous, pioneer elements including Caryophyllaceae, Rumex-Oxyria, Artemisia, Chenopodiaceae and Polygonum viviparum, as well as abundant lycopods and ferns. The lake contained the algae Botryococcus and was surrounded by a fringe of mire vegetation with Equisetum, Sphagnum and fungi.

Sediments with a sedimentary/pollen sequence similar to the interstadial sediments outlined above have not been earlier described from Finnish Lapland, and the interstadial is here defined as the Tulppio Interstadial (Tulppio is the nearest hamlet to the Sokli basin; Fig. 5). The preceding cold stage interval is numbered stadial 2 . An OSL date of $48 \pm 16 \mathrm{ka}$ for the deglacial sediments and an AMS ${ }^{14} \mathrm{C}$ date of $42,450 \pm 3,570 \mathrm{yr}$ BP (corresponding approximately to 46 ka calendar years) for the uppermost part of the silt-clay sequence, combined with stratigraphy, strongly suggest that stadial 2 and the Tulppio Interstadial correlate to MIS 4 and part of MIS 3 dated in the marine record at around 70 and between 60-28 ka, respectively (Figs. 3 and 4).

The large error limits on both the luminescence and radiocarbon date, however, hamper a precise correlation of the Tulppio Interstadial with the Middle Weichselian interstadial sequence in the northwest European mainland climate/chrono-stratigraphy or the $\mathrm{D} / \mathrm{O}$ climate sequence distinguished for the Middle Weichselian in the high-resolution Greenland ice record. A first comparison suggests that the Tulppio Interstadial correlates to Interstadial 14 dated at ca. 50 $\mathrm{ka}$ in the Greenland oxygen-isotope record (Johnsen et al., 2001), as the first warm interstadial (Interstadial 16) following the very cold MIS 4 might not have lasted long enough for the Sokli area to get deglaciated and for a shrub tundra vegetation to develop on the deglaciated land. A series of AMS radiocarbon datings of plant macrofossils from the Tulppio siltclay sequence are presently in progress, and the sediments are also being analysed for the possible occurrence of tephra to be correlated with the north Atlantic marine tephrochronoloy for MIS 5-2 (Wastegård \& Rasmussen, 2001; Rasmussen et al., 2003).

Although sediments with a sedimentary/pollen sequence that could correlate to glacio-lacustrine environmental conditions in the Sokli basin and a shrub tundra vegetation in the Sokli area, predating the LGM, have not been described from northern Finland, a second phase of glaciation/deglaciation of a proposed Early or Middle Weichselian age is distinguished in the till and morpho-stratigraphy of eastern-central Lapland (Johansson, 1995; Johansson \& Kujansuu, 1995). The deglaciation phase is indicated 
by the till-covered eskers of system B, which consist of generally continuous ridges with N/NNE-S/SSW orientation (Fig. 5). These eskers occur in the same region, i.e. including Sokli, as where the so called 'Old Northern Till unit' with its northern till fabric is found. It is possible that during the Middle Weichselian, the western part of central Finnish Lapland remained glaciated, as also is suggested by the ice-marginal lacustrine conditions at Sokli during the Tulppio Interstadial.

\subsection{Stadial I of Middle/Late Weichselian age and the Holocene (MIS 3-I)}

Stadial 1 represents the last phase of glaciation of the Sokli area by the Fennoscandian Ice-Sheet. The corresponding till bed reaches a thickness of about $2 \mathrm{~m}$ in the central basin (units Q-R in Fig. 3). Permanent ice-cover started most probably during the later part of MIS 3 and lasted into the Early Holocene. The deglaciation of eastern-central Finnish Lapland is dated at ca. 10,600 (calender) years ago (Johansson and Kujansuu, 2005).

The sediment sequence that overlies the uppermost till bed in the Sokli basin, which includes glacio-fluvial gravels and sands (unit S) fining up to lacustrine sands and silts (containing abundant macrofossil remains of Equisetum sp.; unit T), which then grade into the surface peat deposit (unit $\mathrm{U}$ ), have been described for the basin's margin (borehole 902 in Figure 2). The pollen sequence in the peat registers the gradual establishment of the present-day northern boreal forest in the Sokli area and of the modern Carex fen in the Sokli basin (pollen zone VIb in Fig. 4). The pollen assemblage in sands directly underlying the surface peat deposit, with high pollen percentages for tree birch and dwarf birch, reflects a forest limit vegetation (zone VIa). An aquatic depositional environment is indicated by the presence of the algae Zygnema, and the surrounded wetland vegetation included Cyperaceae, Umbelliferae and Cruciferae.

Johansson (1995) correlates the Younger Till unit of eastern-central Lapland (with W fabric) with the end phase of the main Middle/Late Weichselian gla- ciation, and the Youngest Till unit and eskers without till cover (esker system A) with the last deglaciation phase. The eskers of system A (Fig. 5) are tens of meters high and the most fresh looking with steep flanks and sharp ridges (Johansson \& Kujansuu, 1995). They run in a fan-like pattern from the ice-divide area to $\mathrm{SE}, \mathrm{S}$ and to NE/NNE, and continue all the way to the marginal formations of the Younger Dryas. Their orientation corresponds to the till fabric of the Youngest Till unit. In the till stratigraphy of central Lapland (Hirvas, 1991), Till Bed II is thought to represent the main Weichselian glaciation. Depending on the situation to the ice-divide, Till Bed II has a WNW-WSW fabric. The youngest Till Bed I is associated with the melting phase of the last glaciation.

\section{Stratigraphic correlation with Swedish Lapland and Weichselian ice-limits}

The recognition of only one interstadial interval of Weichselian age in the stratigraphy of Finnish Lapland (Korpela, 1969; Hirvas, 1991) has for long formed a major problem concerning stratigraphic correlation with Swedish Lapland. In the Late Quaternary stratigraphic scheme of Swedish Lapland, i.e. a region situated closer to the center(s) of ice-sheet build-up and final decay in the Fennoscandian mountain chain (Fig. 1), two deglaciation phases are distinguished for the Weichselian predating the LGM (Lagerbäck \& Robertsson, 1988). The ice-free intervals are reflected by the sediments and their pollen that have accumulated in kettle holes formed in a series of till-covered NW-SE directed eskers in northeastern Norrbotten. Pollen from two organic-bearing deposits, separated from each other by till, reveal similar interstadial vegetation developments, including open herb and shrub tundra vegetation being interrupted by an interval during which patches of tree birch might have been present in the area forming open park tundra. A more continental and drier climate is inferred for the younger interstadial.

The pollen record for the older interstadial interval is composite and based on combining data from the 
Onttovaara, Onttoharjut, Takanenmännikkö and Riipiharju sites (Fig. 1; Lagerbäck \& Robertsson, 1988). This interstadial has been correlated with the Peräpohjola Interstadial of Finnish Lapland (Korpela, 1969) and the northwest European mainland Brørup Interstadial (MIS 5c). The younger interstadial has been given the local name of Tärendö Interstadial, with the Riipiharju site as type locality, and correlated with the Odderade Interstadial (MIS 5a). The eskers on which the two interstadial deposits are found occur associated with the so called 'Veiki moraine', which as an impressive hummocky morainic belt can be traced over a distance of some $200 \mathrm{~km}$ parallel to the mountains in the west (Fig. 1; e.g. Hättestrand, 1998).

Our stratigraphy in the Sokli basin now opens the possibility for stratigraphic correlation between Finnish and Swedish Lapland. According to the Sokli stratigraphy, the older interstadial deposit in Swedish Norrbotten correlates with the Sokli Interstadial and not with the Peräpohjola Interstadial. This means that a local name should be given to the older interstadial in Sweden. Instead, it is the younger interstadial defined as the Tärendö Interstadial that would correlate to the Finnish Peräpohjola Interstadial (and the later defined Maaselkä Interstadial; Hirvas, 1991). It is very implausible to correlate the Tärendö Interstadial with the Middle Weichselian Tulppio Interstadial as defined in the Sokli basin. The latter correlation would mean the seemingly unlikely situation of park tundra with possible patches of tree birch close to the mountains in Sweden, and shrub tundra vegetation in an ice-marginal environment far to the east at Sokli. Firm correlation, however, is only possible after obtaining independent absolute age control for the Swedish sediments.

Whereas Swedish Norrbotten appears to have been glaciated during MIS 5d, as indicated by the eskers underlying the older stadial deposit, the Sokli area to the east was during this time interval covered with open tundra vegetation (stadial 4 in the Sokli basin). This would place the maximum extent of the MIS $5 \mathrm{~d}$ glaciation in western Finnish Lapland (Fig. 1). Pronounced till-covered ice-marginal landforms in the Pudasjärvi area of Finnish Northern Ostroboth- nia (Sutinen, 1984; Fig. 1) probably mark the NE ice-limit of the MIS $5 \mathrm{~b}$ glaciation, i.e. when Finnish Lapland appear to have been entirely glaciated (see above). The Pudasjärvi moraines mark the southern limit of the Lower Till unit in the composite stratigraphic scheme of Korpela (1969; Sutinen, 1992). Permanent ice-cover during the interstadial intervals MIS $5 \mathrm{c}$ and $5 \mathrm{a}$ was most probably restricted to the Fennoscandian mountains (Lundqvist, 1992).

The maximum ice-extents during MIS 4 and 2 (LGM at ca. $20 \mathrm{ka}$ ) in Figure 1 are according to Svendsen et al. (2004). Little information exits on ice retreat during MIS 3. Eskers with an approximate N-S direction (esker system B; Johansson, 1995; Johansson \& Kujansuu, 1995) and ice-marginal lacustrine conditions bordered by shrub tundra vegetation at ca. $50 \mathrm{ka}$ (Tulppio Interstadial in the Sokli Basin) are recorded in eastern-central Finnish Lapland (Fig. 1). The existence of large ice-free areas in Fennoscandia during MIS 3 has been suggested by radiocarbon dates from Finnish fossil mammoth bones (Ukkonen et al, 2000). The latter data includes glacially transported remains of mammoth molar dated at 31,970 $\pm 950 \mathrm{yr} \mathrm{BP}$ (corresponding approximately to $34 \mathrm{ka}$ calendar years) at the Iijoki site in northern Ostrobothnia (Fig. 1).

A widespread occurrence of interstadial deposits of MIS 3 age in southwestern Finnish Lapland has been recently suggested by Mäkinen (2005). A large series of organic beds with mostly birch-dominated pollen assemblages resembling those of the Peräpohjola and Maaselkä Interstadial deposits, found both in the lower parts of Till Bed II and between Till Bed II and the underlying glacio-fluvial formations, were dated by ${ }^{14} \mathrm{C}$, TL or OSL dating. From the twenty samples dated by ${ }^{14} \mathrm{C}$, more than half of the samples gave infinite ages. Finite ages varied from 43 to 53 ka, i.e. at the limit of the method's range of accuracy, and as the results were obtained from bulk sampled which can easily be contaminated with for instance plant roots (with even tiny amounts resulting in considerable too young ages), these dates alone, however, can not be considered reliable. Organic beds measured by TL were mostly dated between $37-55 \mathrm{ka}$, 
whereas OSL dating resulted in a much larger range of ages from $41-117 \mathrm{ka}$. TL and OSL dating on the same sediments (i.e. the Kauvonkangas site) gave ages of $55 \mathrm{ka}$ (depth $5.5 \mathrm{~m})$ and 57-66 ka (2.5-3.0 m), respectively. At this point we consider it unclear whether the differences between the TL and OSL dating results are due to methodological differences or are an indicator of a real age difference between the dated samples. Therefore, we consider the apparent MIS 3 ages obtained on the interstadial beds of southwestern Finnish Lapland as still preliminary until more information on the quality of the dates (e.g. assumed sample water content) have been presented.

Extensive ice-front retreat in the eastern sector of the Fennoscandian Ice-Sheet during MIS 3 has been recently suggested by Sarala (2005). Based on a comprehensive study of the Weichselian stratigraphy, geomorphology and glacial dynamics in southern Finnish Lapland, the latter paper presents two alternative interpretations regarding the Weichselian glacial history of Finnish Lapland. Model 1, which is in agreement with our interpretations, includes a MIS 5b glacial margin at the Pudasjärvi moraines and a MIS 4 ice extent into Russia. However, we additionally recognize a distinct phase of ice-front retreat during MIS 3 that left southern and central Finland ice-free. Their Model 2 considers the Pudasjärvi moraines and other ice-marginal formations in western-central Lapland as representing different stages in ice-front retreat during MIS 3 that left major part of Finland ice-free. We consider Model 1 with in addition icefront retreat during MIS 3 as the most plausible model in the availability of the present data, including the bio-stratigraphic evidence, but conclude that absolute age determinations are necessary for the Pudasjärvi ice-marginal formations to come to a final correlation of data.

\section{Conclusions}

The Late Quaternary climate-stratigraphy at Sokli in eastern-central Finnish Lapland, the associated, main environmental changes both in the Sokli area and within the Sokli basin, and the independent ab- solute chronology for the sediment sequence are summarized in Figure 6a. The recorded ice-free intervals at Sokli during the Weichselian have been marked as hatched intervals in the stacked marine oxygen isotope record indicated directly to the left (Martinson et al., 1987). The latter record is a proxy for global ice volumes and deep-sea temperature (Shackleton, 1987). Our correlation with the till and esker-stratigraphy of eastern-central Lapland (Johansson, 1995; Johansson \& Kujansuu, 1995) is given to the right in Figure 6a.

The results obtained in Helmens et al. (2000) and the present study indicate that the non-glacial sediment layers in the Sokli sequence each have a charateristic lithological and pollen content. The warm stage deposits, and the cold stage deposit corresponding to the first cold interval of Weichselian age, represent individual and successive developments both in terms of depositional and vegetational change. This indicates that these sediments are not the result of re-deposition, but occur in situ, which is a very important conclusion to be drawn for a site which was repeadedly glaciated during the Weichselian. The lithological and palynological data allow us to define a sequence of Late Quaternary climate-stratigraphic units for the Sokli basin, and this data combined with the independent OSL/AMS ${ }^{14} \mathrm{C}$ chronology obtained for the Sokli sediments, allow a correlation with the well-dated oxygen-isotope climate-stratigraphy of the deep-sea. The Sokli sequence shows both for the cold and warm stages of the Weichselian progressively colder conditions as the period evolves, in agreement with the deep-sea record.

Climate has been the main basis for stratigraphic division of Late Quaternary deposits in Fennoscandia, and the climate-stratigraphic sequence presented here provides us with an important stratigraphic framework for the detailed studies of the Sokli sediments that are presently in progress. A division of the Sokli sedimentary sequence into allo-stratigraphic units, Biozones, and eventually possible chronostratigraphic units to be applicable to the climate region of eastern Fennoscandia (see also Gibbard \& West, 2000), will be our next stratigraphic goal. 


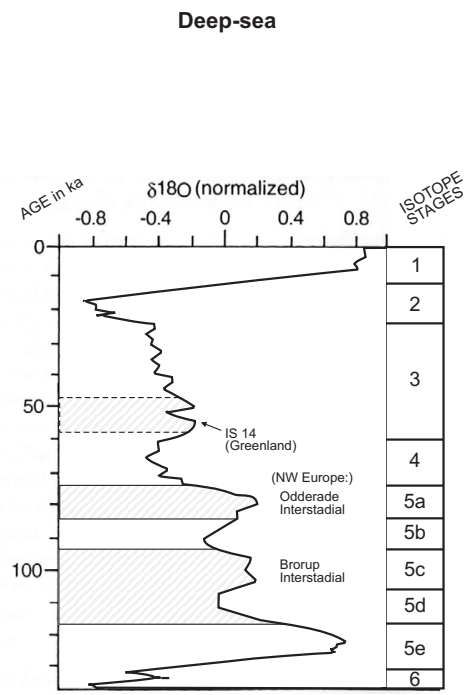

A

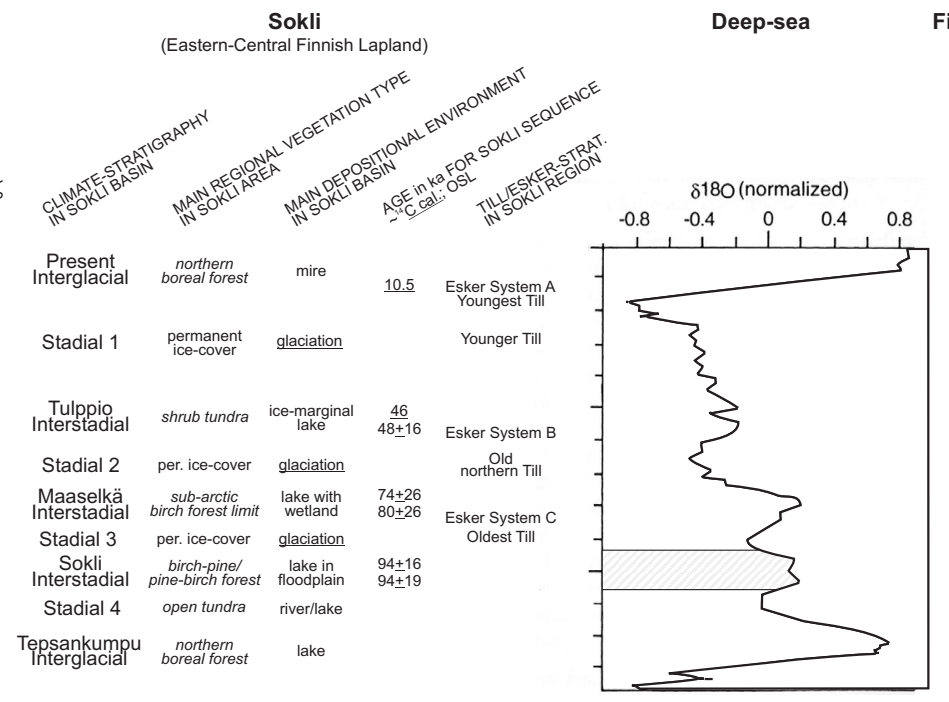

B

innish Lapland

Fig. 6. The stacked marine oxygen isotope record for the Late Quaternary (Martinson et al., 1987), with indicated intervals of ice-free conditions (hatched intervals) in Finnish Lapland during the Weichselian (MIS 5d-2) according to A: the stratigraphy in the Sokli basin, and B: the composite stratigraphic schemes of Korpela (I969) and Hirvas (I99I). Summarized are also past environmental conditions at Sokli and the till and esker-stratigraphy in the Sokli region (Johansson, 1995; Johansson \& Kujansuu, 1995).

Our study of the Sokli sediments leads to a major departure from earlier reconstructions regarding the glacial history of northeastern Fennoscandia. Earlier studies based on long-distance correlation of litho- and bio-stratigraphic fragmentary evidence had suggested that Finnish Lapland was ice-covered for a major part of the Weichselian (Korpela, 1969; Hirvas, 1991; Fig. 6b). Deglaciation was thought to have occurred during the Maaselkä/Peräpohjola Interstadial which had been tentatively correlated to MIS 5c. However, the long and near continuous Sokli sequence indicates that the area which corresponds to the easternmost part of the Late Weichselian ice-divide zone of the Fennoscandian Ice-Sheet became glaciated for the first time only during the second cold stage of the Early Weichselian (MIS 5b; Fig. 6a). Thereafter the area became ice-free twice. First during the Maaselkä Interstadial (dated to MIS 5a). The youngest interval of ice-retreat most probably occurred during an interstadial of Middle Weichselian age (MIS 3). The stratigraphy in the Sokli basin conforms to the till and esker-stratigraphy of eastern- central Lapland by Johansson (1995) and Johansson \& Kujansuu (1995), indicating two phases of glaciation-deglaciation during the Weichselian predating the LGM (Fig. 6a).

\section{Acknowledgements}

We kindly thank Mr. Hannu Hirvasniemi and Mr. Seppo Putkinen (Geological Survey of Finland) for coring operations, Mrs. Raija-Liisa Huttunen (University of Oulu) for preparation of pollen samples, and Mrs. Viena Arvola (Geological Survey of Finland) for the drawing of Figures 1 and 3. Coring was financed by the Geological Survey of Finland. Thank is also due to the Arctic Centre (University of Lapland, Rovaniemi, Finland) for providing the logistic support to make a detailed description and multiproxy sampling of the Sokli A/B -series boreholes. Dr. Matti Saarnisto, Dr. Pertti Sarala and an anonymous reviewer are thanked for their comments on the manuscript. 


\section{References}

Aario, L., 1940. Waldgrenzen und subrezenten pollenspektren in Petsamo Lappland. Annales Academiae Scientiarum Fennicae A. LIV. 8, 120 p.

Ahti, T., Hämet-Ahti, L. \& Jalas J., 1968. Vegetation zones and their sections in northwestern Europe. Annales Botanici Fennici 5, 169-211.

Allen, J.R.M., Brandt, U., Brauer, A., Hubberten, H.W., Huntley, B., Keller, J., Kraml, M., Mackensen, A., Mingram, J., Negendank, J.F.W., Nowaczyk, N.R., Oberhänsli, H., Watts, W.A., Wulf, S. \& Zolitschka, B., 1999. Rapid environmenetal changes in southern Europe during the last glacial period. Nature 400, 740-743.

Andersen, B.G. \& Mangerud, J., 1989. The Last Interglacial-Glacial cycle in Fennoscandia. Quaternary International 3/4, 21-29.

Atlas of Finland, 1992. Folio 131, Climate, Map Centre, Helsinki.

Behre, K.E., 1989. Biostratigraphy of the last glacial period in Europe. Quaternary Science Reviews 8, 25-44.

Boulton, G.S., Dongelmans, P., Punkari, M. \& Broadgate, M., 2001. Palaeoglaciology of an ice sheet through a glacial cycle: the European ice sheet through the Weichselian. Quaternary Science Reviews 20, 591-625.

Donner, J., 1988. The Eemian site of Norinkylä compared with other interglacial and interstadial sites in Ostrobothnia, Western Finland. Annales Academiae Scientiarum Fennicae A III 149, 31 p.

Donner, J., 1995. The Quaternary History of Scandinavia. Cambridge University Press, Cambridge, 200 p.

Donner, J., 1996. The Early and Middle Weichselian interstadials in the central area of the Scandinavian glaciations. Quaternary Science Reviews 15, 471-479.

Donner, J., Korpela, K. \& Tynni, R., 1986. Veiksel-jääkauden alajaotus Suomessa (The subdivision of the Weichselian stage in Finland). Terra 98, 240-247.

Flora of North-East of European part of USSR, 1976. V2, Leningrad, Nauka.

Forsström, L., 1982. The Oulainen Interglacial in Ostrobothnia, western Finland. Acta Universitatis Ouluensis A $136,116 \mathrm{p}$.

Forsström, L., 1988. The northern limit of pine forest in Finland during the Weichselian interstadials. Annales Academiae Scientiarum Fennicae A III 147, 27 p.

Forsström, L., 1990. Occurrence of larch (Larix) in Fennoscandia during the Eemian interglacial and the Brørup interstadial according to pollen analytical data. Boreas $19,241-248$.

Forsström, L., 1991. The Early Weichselian climate in Finland. Norsk Geologisk Tidsskrift 71, 133-136.

Gibbard, P.L. \& West R.G., 2000. Quaternary chronostratigraphy: the nomenclature of terrestrial sequences. Boreas 29, 329-336.

Guiot, J., Pons, A., De Beaulieu, J.L. \& Reille, M., 1989. A 140,000-year continental climate reconstruction from two European pollen records. Nature 338, 309-313.
Helmens, K.F., Räsänen, M.E., Johansson, P.W., Jungner, H. \& Korjonen, K., 2000. The Last Interglacial-Glacial cycle in NE Fennoscandia: a nearly continuous record from Sokli (Finnish Lapland). Quaternary Science Reviews 19, 1605-1623.

Hicks, S., 1994. Present and past pollen records of Lapland forests. Review of Palaeobotany and Palynology $82,17-35$.

Hirvas, H., 1991. Pleistocene stratigraphy of Finnish Lapland. Geological Survey of Finland, Bulletin 354, 123 p.

Hättestrand, C., 1998. The glacial geomorphology of central and northern Sweden. Sveriges Geologiska Undersökning Ser. Ca 85, 47 p.

Ignatius, H., Korpela, K. \& Kujansuu, R., 1980. The deglaciation of Finland after 10,000 B.P. Boreas 9, 217228.

Igoshina, K.N., 1963. The larch (Larix) in the Urals. Materials of the history of the flora and vegetation of the USSR. The USSR Academy of Sciences, Moscow-Leningrad, p. 462-492 (in russian).

Ilvonen, E., 1973a. Eem-Kerrostuma Savukosken Soklilla. Geologi 25, 81-84.

Ilvonen, E., 1973b. Eem-interglasiaalinen kerrostuma Savukosken Soklilla, Pohjois-Suomessa, orgaanisten kerrostumien ja glasiaaligeologisen tutkimuksen valossa. Unpublished PhLic thesis, University of Turku, Finland, $144 \mathrm{p}$.

Johansson, P.W., 1995. The deglaciation in the eastern part of the Weichselian ice divide in Finnish Lapland. Geological Survey of Finland, Bulletin 383, 72 p.

Johansson, P.W. \& Räsänen, M., 1994. Nya preliminära undersökningar av moräntäckta organiska avlagringar i Sokli, Norra Finland. Abstracts 21:a Nordiska geologiska vintermötet, Luleå, p. 92.

Johansson, P.W. \& Kujansuu, R., 1995. Observations of three subglacial drainage systems (eskers) of different ages in Savukoski, eastern Finnish Lapland. Geological Survey of Finland, Special Paper 20, 83-93.

Johansson, P.W. \& Kujansuu, R., 2005. Deglasiaatio. In: Johansson PW and Kujansuu R (eds.) Pohjois-Suomen maaperä, maaperäkarttojen 1:400 000 selitys. Geological Survey of Finland, Espoo, pp. 149-156.

Johnsen, S.J., Dahl-Jensen, D., Gundestrup, N., Steffensen, J.P., Clausen, H.B., Miller, H., Masson-Delmotte, V., Sveinbjörnsdottir, A.E. \& White, J., 2001. Oxygen isotope and palaeotemperature records from six Greenland ice-core stations: Camp Century, Dye-3, GRIP, GISP2, Renland and NorthGRIP. Journal of Quaternary Science 16, 299-307.

Kleman. J, Hättestrand, C. \& Clarhäll, A., 1999. Zooming in on frozen-bed patches: scale-dependent controls on Fennoscandian ice sheet basel thermal zonation. Annals of Glaciology 28, 189-194.

Korpela, K., 1969. Die Weichsel-eiszeit und ihr intersta- 
dial in Peräpohjola (nördliches Nordfinnland) im licht von submoränen sedimenten. Annales Academiae Scientiarum Fennicae A. III. 99, 1-108.

Kujansuu, R. \& Eriksson, B., 1995. Pre-Late-Weichselian subglacial glaciofluvial system at Vuotso, Finnish Lapland. Geological Survey of Finland, Special Paper 20, 75-82.

Lagerbäck, R. \& Robertson, A.M., 1988. Kettle holes stratigraphical archives for Weichselian geology and palaeoenvironment in northernmost Sweden. Boreas 17, 439-468.

Lundqvist, J., 1992. Glacial stratigraphy in Sweden. Geological Survey of Finland, Special Paper 15, 43-59.

Mangerud, J., 1991. The Scandinavian Ice Sheet through the last interglacial/glacial cycle. In: Frenzel, B (ed.) Klimageschichtliche Probleme der letzten 130000 Jahre. G. Fischer, Stuttgart, 307-330.

Martinson, D.G., Pisias, N.G., Hays, J.D., Imbrie, J., Moore, T.C. \& Shackleton. N.J., 1987. Age dating of the orbital theory of the Ice Ages: development of a highresolution 0 to 300,000-year chronostratigraphy. Quaternary Research 27, 1-29.

Murray, A.S. \& Wintle, A.G., 2000. Luminescence dating of quartz using an improved single aliquot regenerative-dose protocol. Radiation Measurements 32, 57-73.

Mäkinen, K., 2005. Dating the Weichselian deposits of southwestern Finnish Lapland. Geological Survey of Finland, Special Paper 40, 67-78.

Prentice, I.C., 1978. Modern pollen spectra from lake sediments in Finland and Finnmark, north Norway. Boreas $7,131-153$.

Rasmussen, T.L., Wastegård, S., Kuijpers, A., van Weering, T.C.E. \& Heinemeier, J., 2003. Stratigraphy and distribution of tephra layers in marine sediment cores from the Faeroe Islands, North Atlantic. Marine Geology 199, 263-277.

Ritchie, J., 1974. Modern pollen assemblages near the arctic tree line, Mackenzie Delta region, Northwest Territories. Canadian Journal of Botany 52, 381-396.

Saarnisto, M., Eriksson, B. \& Hirvas, H., 1999. Tepsankumpu revisited - pollen evidence of stable Eemian climates in Finnish Lapland. Boreas 28, 12-22.

Saarnisto, M. \& Lunkka, J.P., 2004. Climate variability during the last interglacial-glacial cycle in NW Eurasia. In: Battarbee, R.W., Gasse, F. \& Stickley, C.E. (eds.) Past climate variability through Europe and Africa. Developments in Paleoenvironmental Research 6, 443-464.

Sarala, P., 2005. Weichselian stratigraphy, geomorphology and glacial dynamics in southern Finnish Lapland. Bulletin of the Geological Society of Finland 77, 71-104.

Shackleton, N.J., 1987. Oxygen isotopes, ice volume and sea level. Quaternary Science Reviews 6, 183-190.

Siegert, M.J., Dowdeswell, J.A. \& Melles, M., 1999. Late Weichselian glaciation of the Eurasian High Arctic. Quaternary Research 52, 273-285.

Sutinen, R., 1984. On the glacial stratigraphy in Pudasjärvi area, Peräpohjola. Striae 20, 91-94.

Sutinen, R., 1992. Glacial deposits, their electrical properties and surveying by image interpretation and ground penetrating radar. Geological Survey of Finland, Bulletin 359, $123 \mathrm{p}$.

Svendsen, J.I. et al. (29 co-authors), 2004. Late Quaternary ice sheet history of northern Eurasia. Quaternary Science Reviews 23, 1229-1271.

Ukkonen, P., Lunkka, J.P., Jungner, H. \& Donner, J., 1999. New radiocarbon dates from Finnish mammoths indicating large ice-free areas in Fennoscandia during the Middle Weichselain. Journal of Quaternary Science 14, 711-714.

Van Geel, B., Hallewas, D.P. \& Pals, J.P., 1983. A Late Holocene deposit under the Westfriese Zeedijk near Enkhuizen (Prov. of Noord Holland, The Netherlands): Palaeoecological and archaeological aspects. Review of Palaeobotany and Palynology 38, 269-335.

Vartiainen, H., 1980. The petrography, mineralogy and petrochemistry of the Sokli carbonatite massif, northern Finland. Geological Survey of Finland, Bulletin 313, $126 \mathrm{p}$.

Wastegård, S. \& Rasmussen, T.L., 2001. New North Atlantic tephra horizons from oxygen isotope 5: correlation potential for terrestrial, marine and ice-core archives. Quaternary Science Reviews 20, 1587-1593.

Zagwijn, W.H., 1985. An outline of the Quaternary stratigraphy of the Netherlands. Geologie en Mijnbouw 64, $17-24$. 